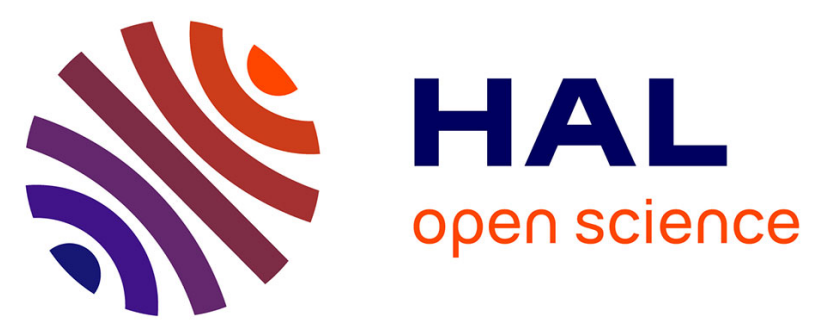

\title{
Lower Mediterranean plain accelerated evolution during the Little Ice Age: Geoarchaeological insight in the Tech basin (Roussillon, Gulf of Lion, Western Mediterranean)
}

Jean-Michel Carozza, Carole Puig, Thierry Odiot, Philippe Valette, Olivier

Passarius

\section{To cite this version:}

Jean-Michel Carozza, Carole Puig, Thierry Odiot, Philippe Valette, Olivier Passarius. Lower Mediterranean plain accelerated evolution during the Little Ice Age: Geoarchaeological insight in the Tech basin (Roussillon, Gulf of Lion, Western Mediterranean). Quaternary International, 2011, 266, pp.94104. halshs-01065734

\section{HAL Id: halshs-01065734 \\ https://shs.hal.science/halshs-01065734}

Submitted on 18 Sep 2014

HAL is a multi-disciplinary open access archive for the deposit and dissemination of scientific research documents, whether they are published or not. The documents may come from teaching and research institutions in France or abroad, or from public or private research centers.
L'archive ouverte pluridisciplinaire HAL, est destinée au dépôt et à la diffusion de documents scientifiques de niveau recherche, publiés ou non, émanant des établissements d'enseignement et de recherche français ou étrangers, des laboratoires publics ou privés. 


\title{
Lower Mediterranean plain accelerated evolution during the Little Ice Age: Geoarchaeological insight in the Tech basin (Roussillon, Gulf of Lion, Western Mediterranean)
}

\author{
Jean-Michel Carozza ${ }^{\mathrm{a}, \mathrm{d}, *}$, Carole Puig ${ }^{\mathrm{b}}$, Thierry Odiot $^{\mathrm{c}}$, Philippe Valette ${ }^{\mathrm{d}}$, Olivier Passarrius ${ }^{\mathrm{e}}$ \\ ${ }^{a}$ University of Strasbourg, Department of Geography, 3 rue de l'Argonne, 67000 Strasbourg, France \\ ${ }^{\mathrm{b}}$ FRAMESPA, UMR 5136, France \\ 'Service Regional de l'Archeologie, France \\ ${ }^{\mathrm{d}}$ GEODE, UMR 5602, France \\ e Pole Archeologique Départemental, France
}

\section{A R T I C L E I N F O}

Article history:

Available online $\mathrm{xxx}$

\begin{abstract}
A B S T R A C T
This paper discusses the evolution of the Tech river lower plain, (western Mediterranean) from the Late Middle Ages, using geomorphological, archaeological and historical data. Geoarchaeological data was obtained from coring and trenching near a buried village and chapel. Radiocarbon and archaeological dating are used to reconstitute sedimentation rates and major flood event chronology. Additional data about channel avulsion are provided by historical data. Increases in sedimentation rate, flooding plain enlargement and repeated avulsion are identified between the last 13th to 15th century AD. This attests to a shift from low water-level regime (LWR) to flood dominated regime (FDR). Climatic or anthropogenic causes of this change are discussed on the basis of regional synthesis. On the western Mediterranean scale, 1250/1350 AD seems to be a wetter phase, associated with the progressive onset of the Early Little Ice Age phase from 1330 to $1450 \mathrm{AD}$.
\end{abstract}

(c) 2011 Elsevier Ltd and INQUA. All rights reserved.

\section{Introduction}

The Lower Plain of the Central and Western Mediterranean during the last millennium has experienced a considerable acceleration in sedimentation rate. First noticed by Vita-Finzi (1969) and known as "Younger Infill", this episode was first assigned to the post-Roman period. Its importance in coastal and deltaic environments evolution is confirmed by a huge range of geomorphological, geohistorical and geoarchaeological studies around the Western Mediterranean Sea as well in middle valley, lower plain, and delta environments (Fig. 1).

In the middle and lower part of river valleys, historical terrace formation is recorded in southeast Spain (Gutierrez-Elorza and Peña-Monne, 1998; Calmel-Avila, 2000; Schulte, 2002; Baartman et al., 2010). Three rapid alluvial phases centred on 961-1034 cal AD, 1417-1611 cal AD and 1900-1950 AD are identified. In large alluvial plains of Mediterranean tributaries, Benito et al. (2008)

\footnotetext{
* Corresponding author. University of Strasbourg, Department of Geography, 3 rue de l'Argonne, 67000 Strasbourg, France.

E-mail address: carozza@unistra.fr (J.-M. Carozza).
}

synthesised radiocarbon dates on slack-water, which clustered around 990-1160 cal AD and 1430-1660 cal AD, and recorded periods of high fluvial activity. In northeast Spain, Schulte (2002, 2003) also documented an aggradation phase starting around 1360/1400 cal AD. In Languedoc-Roussillon, data are rarer. Small basin and alluvial fan aggradation was reported by Carozza et al. (2008) in the Eastern Pyrenees and by Bruneton et al. (2002) in Central Languedo century. In southeast France, Jorda and Provensal (1996) and Jorda et al. (2002) documented terrace formation during the last millennium. In the Gardon River, Sheffer et al. (2003) have identified large flood deposits from the 16th century to the second half of the 19th century AD.

In the lower plain and delta lobe progradation and avulsion rhythm, acceleration in lagoon sedimentation filling and closing are the main evolutionary trend reported by previous studies. In the Ebro delta, the last millennium corresponds to a major building phase associated with the Riet-Vell lobe (1100-1300 AD), Sol de Riu lobe (1350-1700 AD) and Mitjorn lobe since 1700 AD (Somoza et al., 1998). In the Llobregat delta, three phases of increased sedimentation rate are recorded by Gamez et al. (2005) during the $6-8$ th century AD, 10-14th century AD, and 18th century AD to present. This last episode is strongly correlated with the increase of

1040-6182/\$ - see front matter ( 2011 Elsevier Ltd and INQUA. All rights reserved. doi:10.1016/j.quaint.2011.06.049 


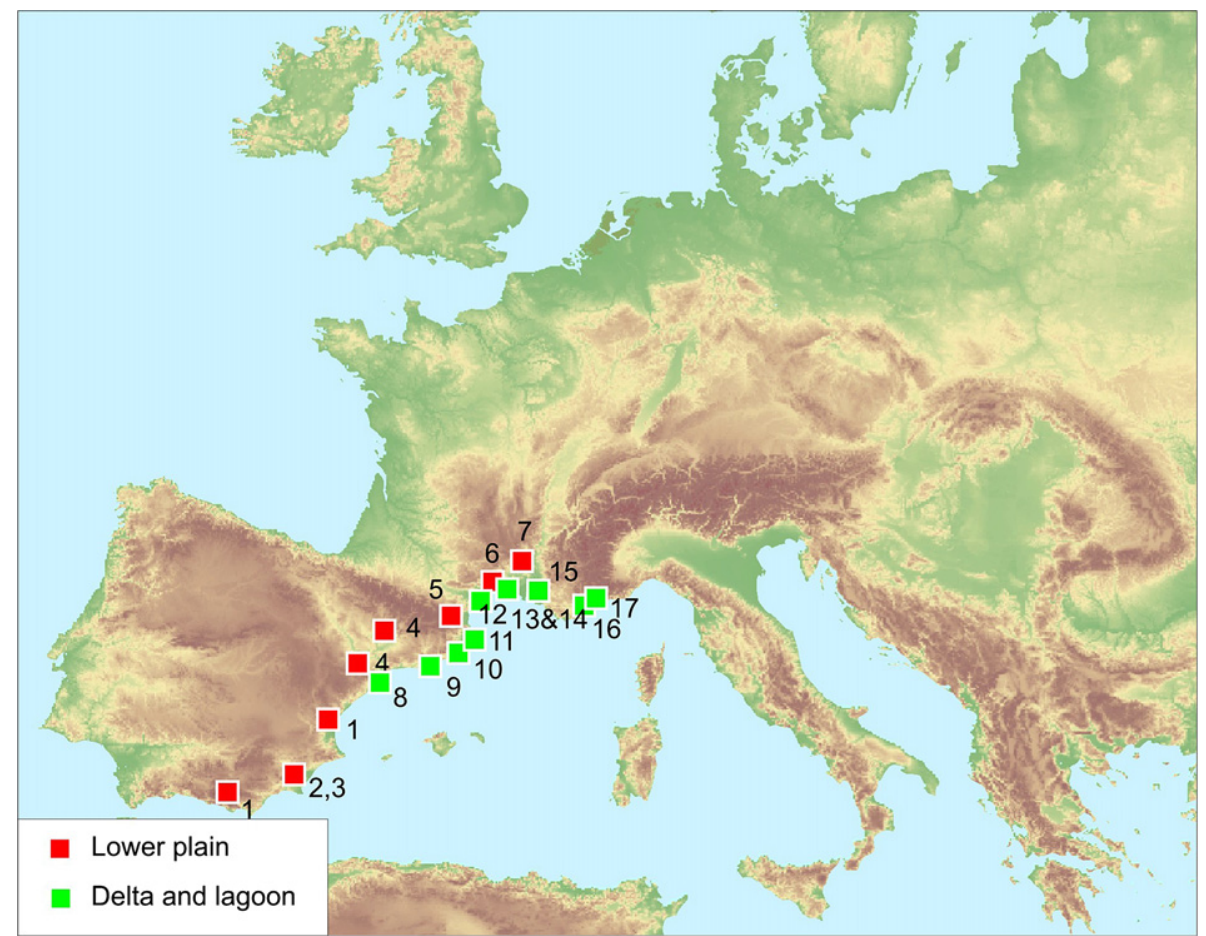

1- Schulte (1998) , 2- Calmel-Avila (2000), 3- Baatmann et al. (2010), 4- Gutierrez-Elorza and Peña Monne (1998), 5-Carozza and al. (2008), 6- Bruneton and al. (2002), 7- Scheffer and al. (2003), 8Somoza and al. (1998), 9- Gamez and al. (2005, 2007), 10- Montaner Roviras and Solà Subiranas (2004), 11- Bach (2005), 12- Verdeil (1969), 13- Jorda (2007), 14- Berger and al. (2008), 15-ArnaudFassetta (2007), 16- Deviller and Bonnet (2007), 17-Sivan and al. (2010).

Fig. 1. Western Mediterranean locations reporting accelerated sedimentation during the last millennium.

flash floods reported by Barrera et al. (2005) and avulsion of the Llobregat River in its terminal delta (Gamez, 2007). Further north, in the Lower Emporda basin, a rapid sedimentation phase seems to have occurred in the Ter River during the 12-14th century AD. Montaner Roviras and Solà Subiranas (2004) document major avulsion in the early 14th century AD. In the same area, Marques and Julia (2006) report the destruction and burial of the Ullà monastery by Ter River flooding at the end of the 12th century AD or the beginning of the 13th century AD. In the High Emporda, a similar evolution is reported by Bach (2005), but the chronological framework remains poorly constrained.

In Central Languedoc, data on small delta evolution during the Middle Ages are sparse. In the Aude delta, major avulsion and an increase in delta progradation is reported by Verdeil (1970) around 1316-1398 and during the 18th century AD. This latest phase is confirmed by recent geohistoric works (Cavero, 2010). More consistent data are available for the Lez delta plain. Near Port Ariane, Jorda (2007) showed a progressive eastern shift in the river during historical time and a post-15th century break in the river dynamics, correlated to the Little Ice Age major phase. In the Vidourle delta, Berger et al. (2010) highlighted an increase in sedimentation rate starting around 1350 and associated with rapid lobe progradation. Surprisingly, the late Middle Age evolution of the Rhone delta is not well documented by field data. According to Arnaud-Fassetta (2007), alluvial dynamics are dominated by low water levels from 1050 to 1550 AD. However, this phase corresponds to the building of the Daladel, Peccais and Bras de Fer lobes (Rey et al., 2009). Moreover, historical data from Pichard and Ricaute (2009) show an increase in flood numbers as early as 1420 and a clustering of extreme events at 1420-1600, 1650-1720 and 1760-1900 AD. To the east, in the Argens valley, Devillers and Bonnet (2006) reported the closing of the northern part of Villepey lagoon and an increased sedimentation rate since 1120 AD. In Nice, Sivan et al. (2010) have recently reported a drastic increase in sedimentation rate during post-9th century AD in the lower urban Brancolar Valley.

The changes during the last millennium play a key-role in present day landscape organization. Despite chronological gaps or inaccuracies, all these studies show evidence for rapid landscape changes during the Late Middle Ages to Modern period in relation with an increase in sediment supply in lower valley and delta environments. Climate or anthropic driven evolution during the Medieval Climate Anomaly/Little Ice Age is still a controversial question in a context of rapid demographic, land use or agricultural practices changes as well as large scale river use and human modification. This paper explores the recent evolution of the lower Roussillon basin using geomorphological, geoarchaeological and historical methods. At a regional scale, palaeogeographical reconstitution is needed for a better understanding of human settlement evolution. More generally, refining the chronology of delta evolution is needed to compare it to socio-economic and climate data, in order to infer the dominant factor controlling and regionally driving delta evolution.

\section{Study area}

The Roussillon basin is the southernmost part of the littoral plain along the French Mediterranean Gulf of Lion (Fig. 2). It is a triangular Neogene sedimentary basin, open on its east side to the Mediterranean Sea. It is bordered at its south and west sides by the axial Pyrenean Mountains (respectively by the Albères and the Canigou massif) and to the north by the pre-Pyrenean carbonate massif of the Corbières. It is mainly constituted of alluvial deposits from Neogene 


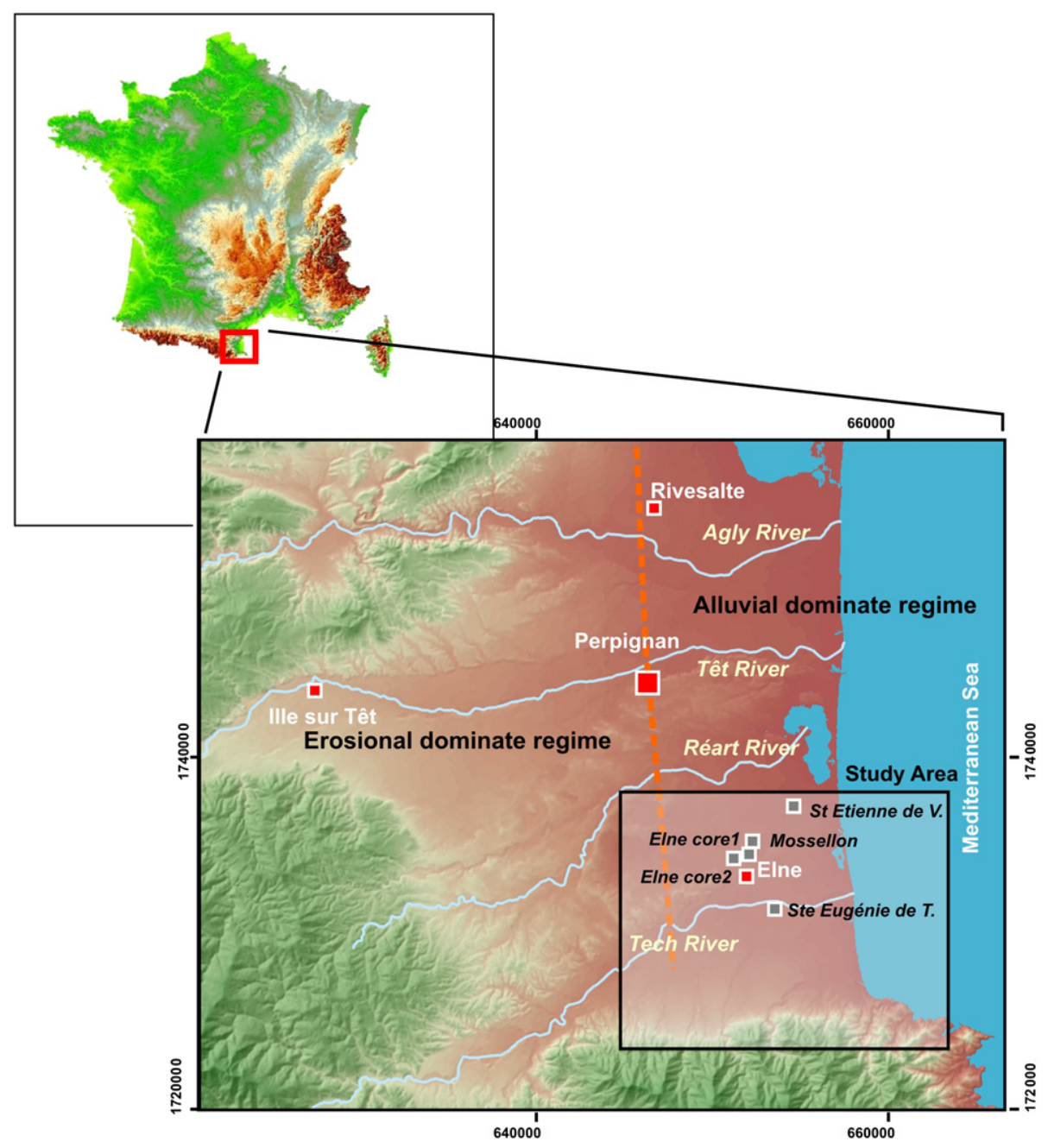

Fig. 2. Study area.

(Oligo-Miocene to Pliocene) and Pleistocene alluvial terraces (Calvet, 1996). The altitude of the plain decreases in the eastern direction, from $230 \mathrm{~m}$ to $0 \mathrm{~m}$ asl. The average slope of the river remains very high close to the sea $(0.2 \%)$, forming a high energy fluvial system.

The drainage pattern is organized into 4 main rivers from north to south (Fig. 2): the Agly River (drainage basin $1045 \mathrm{~km}^{2}$ ) the Têt River $\left(1550 \mathrm{~km}^{2}\right)$, the Reart River $\left(260 \mathrm{~km}^{2}\right)$ and the Tech River $\left(750 \mathrm{~km}^{2}\right)$ that have built up alluvial terraces and alluvial plains (i.e. delta lobe). The current hydrologic regime of these rivers is Mediterranean, with nival influences for the Têt and Tech rivers.

According to the geomorphological organization of the alluvial deposits, the lower plain can be divided into two parts. The western part is characterized by stepped alluvial terraces, even for Late Pleistocene and Holocene deposits (Mussot, 1993; Bisaro and Carozza, 2009). The eastern part corresponds to a continuous alluvial accumulation system. This area corresponds to the preserved midHolocene ( $\sim 4000 \mathrm{BC})$ to present day transgressive and regressive marine to river deposits (Highstand System Track). Each of these rivers has built a more or less complex alluvial multi-lobed system.

Previous studies about late Holocene evolution have pointed out the importance of the Medieval to Modern sedimentation in the lower Roussillon plain. Marichal et al. (1994) mainly focused on the Salanque alluvial plain, i.e. the northern part of the Roussillon basin. Based on observation and archive data, these authors proposed a first model of alluvial plain evolution taking into account both archaeological and historical information. Attention was particularly focused on river avulsion and lobe shift as a possible explanation for taphonomic bias for pre-Roman to Roman archaeological sites. Serrat (2000) used burial of medieval religious buildings as a tool to quantify the recent alluvial aggradation in the lower Agly plain. Based on these data, he recognized three major lobes associated with Late Iron Age to Antiquity, Medieval sensu lato and Modern periods. This work was systematized and completed by Calvet et al. (2002) for the lower Têt valley. Few data are available at present for the lower Tech alluvial plain, in the south part of the Roussillon basin. Nowadays, the Tech alluvial plain is restricted to an area to the south of the Elne - La-Tour-Bas-Elne. During very large floods as in 1932 or 1940, the Tech flows toward the north via two relief lows. One of the aims of this study was to test the possibility of undocumented recurrent or permanent flow to the north during Medieval to Modern times and its possible role in the natural and cultural evolution of the northern zone.

\section{Material and methods}

Field-based data (geomorphology and archaeology) and textual historical data were combined to highlight environmental changes. These sources present significant differences in spatial and chronological resolution. 
Geomorphological and sedimentological data were obtained by coring or mechanical entrenchment. Cores were obtained using a rotational coring platform APAGEO. Sedimentary description allows the identification, characterization and correlation of alluvial architecture elements over a long distance. Correlations are based on sedimentological facies analysis (Miall, 1998), field grainsize estimation (mean and maximum grain-size of the coarse fraction), sequential organisation, and in-situ magnetic susceptibility measurement using ZH Instrument MS30. This last criterion is particularly useful for palaeosol identification and characterization. It is thus possible to determine the spatial extent to the alluvial formation by correlation of this data with industrial coring, referenced in the geological database from BRGM, to build a basin-scale stratigraphic framework.

The alluvial chronology is mainly based on ${ }^{14} \mathrm{C}$ dating (charcoal or plant remains) on the one hand and archaeological dating (ceramic, building stratigraphy) on the other. The dating of alluvial deposits during Medieval to Modern Period by ${ }^{14} \mathrm{C}$ is still imprecise and highly variable in quality due to the existence of radiocarbon plateaus. However, ${ }^{14} \mathrm{C}$ dating on charcoal or plant remains associated with flooding deposits or soil levels was used in order to build a chronostratigraphic framework (Table 1). In addition, chronological data accuracy was improved by taking into account archaeological and historical data. Dating of archaeological artefacts (potsherds, coins) is often controversial due to possible reworking, and commonly is used to define only a terminus post quem. On-site analysis provides numerous artefacts that can assure chronological homogeneity. Coring and trenching near attested archaeological sites can provide a control tool on the chronology obtained by both radiocarbon and archaeological data. In the Roussillon area, Iberian ceramic imports commonly allow dating of archaeological levels with less than 20 years error margin for the period between the late 13 th century and 17 th century AD. In addition, the systematic use of historical archive data often allows reconstituting and refining the evolution of the river location with high chronological precision in a context of rapid avulsion. The references to river position or references to abandoned channels are common in archive sources since the 12 th century AD as spatial tool to delimit property (Puig, 2003). Most of these toponymic elements are still in use in present day land registries and/or are easy to locate, allowing precise dating of channel movement or lobe abandonment (Table 2).

Table 1

Historical sources data used in this study.

\begin{tabular}{|c|c|c|}
\hline Date & Archive source & Site and/or event type \\
\hline 951 & $\begin{array}{l}\text { ADPO, Cartulaire de François } \\
\text { de Fossa, vol. } 2, n^{\circ} 64\end{array}$ & $\begin{array}{l}\text { Sainte-Eugénie-de-Tresmals } \\
\text { early mention }\end{array}$ \\
\hline 956 & Pezin et Chevillot, 1997 & Mill on the Tech River \\
\hline 1264 & Champion 1864 & Flood in Perpignan \\
\hline 1290 & Alart, vol. XI, p. 535 & N-D du Pont in Elne City \\
\hline 1311 & ADPO 3E $1 / 19$ & Old Tech in Tresmals \\
\hline $1345-1350$ & Alart, vol. XIV, p. 213 & N-D du Pont in Elne city \\
\hline 1327 & ADPO $1 B 254 \mathrm{f}^{\circ} 122 \mathrm{v}^{\circ}-123 \mathrm{r}^{\circ}$ & Flood in Roussillon \\
\hline 1332 & ADPO $1 \mathrm{~B} 16 \mathrm{f}^{\circ} 154 \mathrm{v}^{\circ}$ & Food in north Roussillon \\
\hline 1338 & Alart, vol. XIII, p. 567 & Flood in north Roussillon \\
\hline 1340 & ADPO 3J717, Caucanas p. 688 & Flood in Roussillon \\
\hline 1370 & ADPO $1 \mathrm{~B} 90, \mathrm{f}^{\circ} 13$ & Flood in Roussillon \\
\hline 1376 & Alart, vol. M, p. 135 & $\begin{array}{l}\text { Island on the Tech in } \\
\text { Saint-Etienne-de-Villerase }\end{array}$ \\
\hline 1378 & ADPO 1B276 $\mathrm{f}^{\circ} 76 \mathrm{r}^{\circ}-77 \mathrm{r}^{\circ}$ & Flood in Roussillon \\
\hline 1421 & Champion 1864 & Flood in Perpignan \\
\hline 1395 & ADPO 1B156 folio 33 & Boat on the Tech in Taxo \\
\hline 1422 & Alart, vol. J, p. 250 & Old Tech in Mossellon \\
\hline \multirow[t]{2}{*}{1444} & ADPO, G. Bolet, A 108 & Old Tech in \\
\hline & & Saint-Etienne-de-Villerase \\
\hline
\end{tabular}

Table 2

Radiocarbon data.

\begin{tabular}{lclll}
\hline Laboratory code & 14c age $(\mathrm{BP})$ & Material & Period & Cal age $($ cal BC/AD) $\sigma$ \\
\hline Poz-9377 & $1915 \pm 30$ & Charcoal & Antiquity & 5/208 AD \\
Ly-12615 & $800 \pm 40$ & Bone & Medieval & $1167 / 1278 \mathrm{AD}$ \\
Poz-26423 & $840 \pm 30$ & Charcoal & Medieval & $1058 / 1265 \mathrm{AD}$ \\
Poz-27451 & $810 \pm 30$ & Charcoal & Medieval & $1175 / 1271 \mathrm{AD}$ \\
Poz-26420 & $670 \pm 30$ & Charcoal & Medieval & $1275 / 1390 \mathrm{AD}$ \\
Poz-26421 & $890 \pm 30$ & Charcoal & Medieval & $1042 / 1216 \mathrm{AD}$ \\
Poz-26422 & $1180 \pm 30$ & Plan leaf & Medieval & $772 / 963 \mathrm{AD}$ \\
Poz-26413 & $113.5 \pm 0.38$ & Charcoal & Modern & $1693 / 1920 \mathrm{AD}$ \\
Poz-26414 & $685 \pm 30$ & Charcoal & Medieval & $1268 / 1388 \mathrm{AD}$ \\
Poz-26145 & $2540 \pm 40$ & Charcoal & Iron Age & $801 / 539 \mathrm{BC}$ \\
\hline
\end{tabular}

\section{Geoarchaeological record of the last millennium evolution in the Roussillon}

Four cores and two trenches were investigated in the lower Tech river valley to reconstitute the landscape evolution, coupled with archaeological and historical studies.

\subsection{Sainte-Eugenie-de-Tresmall coring and trench}

The Sainte-Eugenie-de-Tresmall chapel is located within the present day flood plain of the Tech River, on its natural levee, around $10 \mathrm{~m}$ asl (Fig. 3). It is one of the smallest and oldest Roman chapels in the Roussillon, mentioned for the first time in 951 AD. Initially, this building was the heart of a small village, now vanished. The unburied upper part of the building seems more recent, and may date from the second half of the 12th century to the beginning of the 13 th century $\mathrm{AD}$ (Passarrius, 2005). Nowadays, the chapel is buried by $1.80 \mathrm{~m}$ of alluvial deposits. This sedimentary sequence shows an alternation of silty to sandy deposits and alluvial soils. Seven main sedimentary sequences are defined based on grain-size and graded-bedding evaluation, palaeosol or archaeological soil recognition (color, structural organization and artefact content) and field magnetic susceptibility measurements.

The substratum of the chapel building is constituted by $0.80 \mathrm{~m}$ of Roman to Late-Roman structureless dark clay to silt alluvial deposits, interpreted as a fluvisol developed on a distal plain. This level (Unit 1) was directly observed in the Sainte-Eugénie trench and showed carved blocs, ceramics and tegulae and was cut by the Sainte-Eugénie core. This level is recovered by $0.60 \mathrm{~m}$ of silty to sandy deposits, ending with a darker horizon enriched with coarse fragments (granite fragments, ceramics), interpreted as the first medieval archaeological soil (Unit 2). This level is correlated with the chapel basement. Above, $0.45 \mathrm{~m}$ of stratified silt and fine sand is observed (Unit 3). The upper part of this sequence shows a darker colour and increase in MS value in relation to dense human occupation. This archaeological soil was largely recognized all around the chapel during the archaeological excavation and is connected with burial opening level. Above, structureless fine to medium sand covers the archaeological level (Unit 4a, 4b). This level marks an increase in the sediment size and the energy of the deposits. This trend is confirmed by the above sequence, $0.60 \mathrm{~m}$ fining-up sands (Unit 5). A well-developed fluvisoil is observed at the top of this level, characterized by bioturbation features and nuciform to subangular structural aggregates. In the absence of anthropic artefacts, this level could correspond to a period of natural pedogenesis. The penultimate sequence shows alternation of undisturbed fine to coarse sands level (Unit 6) related to one or more flooding events. The top of the sedimentary record is a $0.20 \mathrm{~m}$ horizon (Unit 7), enriched in iron fragments and reinforced concrete and showing torrential characteristics. 


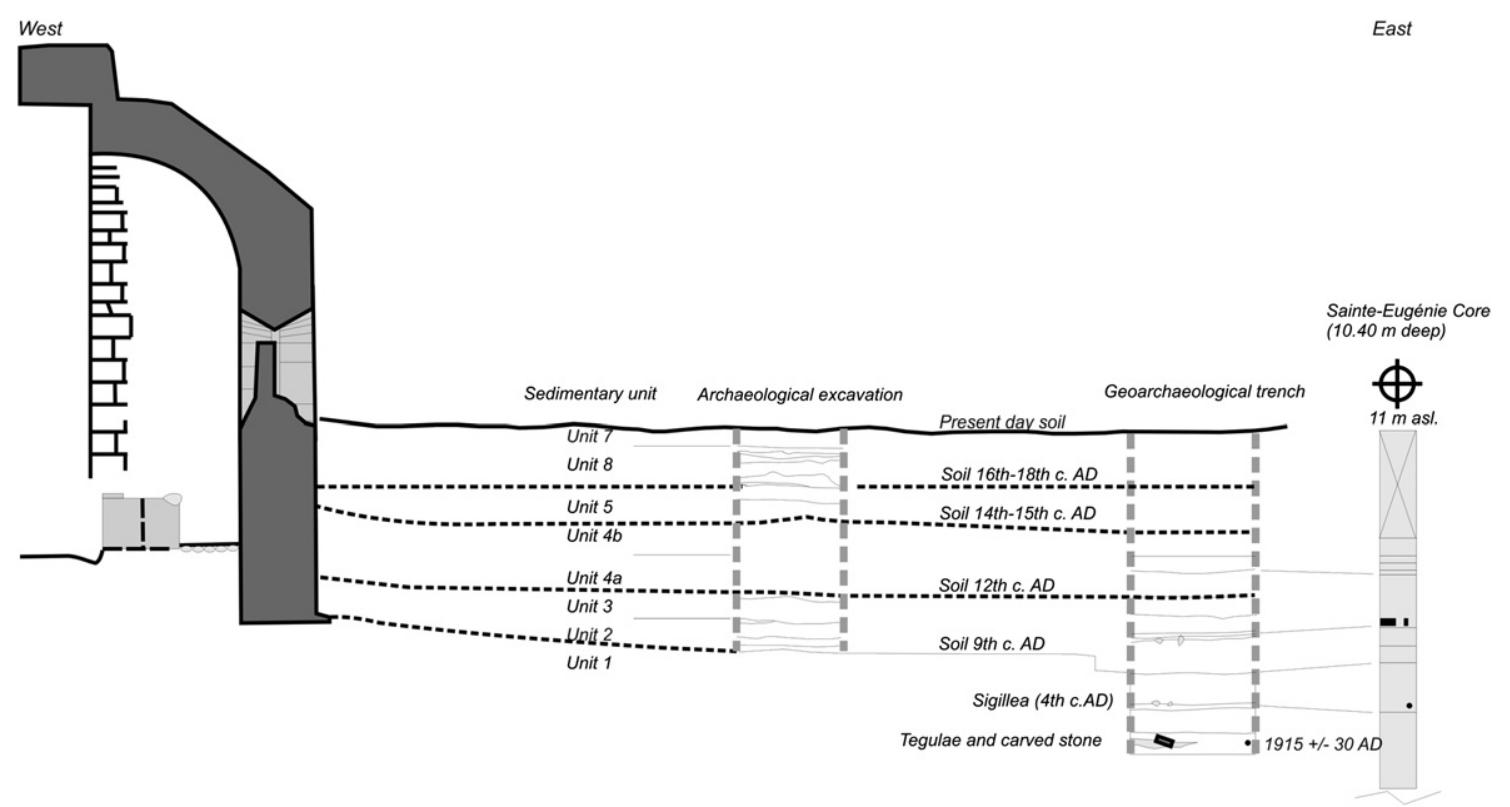

Fig. 3. Alluvial sequence in Saint-Eugénie-de-Tresmal chapel.

The chronology of this sequence can be deduced from two ${ }^{14} \mathrm{C}$ dates and archaeological dating. The pre-Medieval sequence (Unit 1 ) is dated between 4 and $208 \mathrm{AD}$ (Poz-9377) and the 4th century $\mathrm{AD}$ according to archaeological dating on sigillae material (Passarrius, 2005). The basements of the chapel are attributed to the 10th century AD according to both archaeological and historical data, and provide chronology for Unit 2. The oldest mention of the chapel building is 951 AD. The first sandy level (Unit 3) is older than the date of burial, i.e. 1163-1284 AD (Ly 12615). The presence of pedogenetic evolution at the top suggests sufficient time for development. According to this consideration, Unit 4a corresponds to the 1264 AD flood. Unit 3 also records a flood, which could not be attributed to an historical flood event. The chronological attribution of the upper levels is based on archaeological attribution as reported by Passarrius (2005). Unit 4b corresponds to a major flooding event older than the 16th century $\mathrm{AD}$, correlated with the $1421 \mathrm{AD}$ flood event. Unit 5 is overlain by an archaeological level attributed to the 16-17th century AD. The latest units (Unit 6 and 7) record the Modern to Contemporaneous flooding events, including the last major one of 1940 (Unit 7).

\subsection{Elne cores}

Two cores were extracted around the supposed avulsion site of the Tech river, in the north of Elne city, to confirm the shift of the channel in the Elne low (Fig. 4). The first (Elne College, Fig. 4a) is located close to the supposed apex of the north Tech lobe at around $11.5 \mathrm{~m}$ asl. The drill hole, $6.80 \mathrm{~m}$ deep, reached the Pliocene basement at $5.80 \mathrm{~m}$ (Unit 1). The base of the post-Pliocene infill shows $1.00 \mathrm{~m}$ organic to dark-brown structureless clay at the base and dark-brown clay with marked slickensides at the top (Unit 2). Plant remains are abundant at the top of this level. Upper levels (Unit 3, 4 and 5) are fining-up unsorted clastic deposits ranging from pebble, granules, to coarse sand, suggesting a high energy alluvial environment. No organic remains, charcoal or artefacts were found in these levels. In-situ petrographic analysis of the coarser deposits shows gneiss, granite, marble and quartzite as dominant. All the material has no or limited weathering traces.

Additional information is provided by a second core (Elne Station d'épuration, Fig. 4b). The coring site is located $0.6 \mathrm{~km}$ to the northeast of the Elne College core, $7.3 \mathrm{~m}$ asl. The core reached $7.80 \mathrm{~m}$ depth before encountering Pliocene bedrock (Unit 1). The base of the core is dark black structureless clay to $6.10 \mathrm{~m}$ (Unit 2). A major transition occurred at $5.70 \mathrm{~m}$, with fine bedded sand to gravel (Unit 3) organized in 3 fining-up clastic sequences. Unit 4 corresponds to silty to organic-clay strata from 2.90 to $1.80 \mathrm{~m}$ above the surface. The upper part of the sequence show a progressive return to coarse, high energy deposits.

As indicated above, the petrographic spectra agree with deposits of the Tech River according to comparison with the lower terrace pebble spectra noted by Calvet (1996) and Carozza (1998). The absence of significant weathering traces suggests limited transport from Pliocene and alluvial Pleistocene terraces.

The lower parts of the College and Station core (Unit 2) are interpreted as swamp deposits and hydromorphic vertic soil formed close to sea-level. In the College core, the transition from dark clay to sand and pebbles (Unit 3), the scouring contact between the two units, and the absence of progressive enrichment in fine sands in Unit 2 suggest that the sedimentary environment change is related to an abrupt event. The transition in Station core is more gradual. According to ${ }^{14} \mathrm{C}$ dating on Station core, the swamp zone developed from around 770-960 AD. A shift to a fluvial environment is dated in the two cores by ${ }^{14} \mathrm{C}$ dating (Table 1 ). The two dates are in good agreement and indicate that alluvial deposition occurred between the second half of the 11th century to the second half of the 13th century AD. Addition historical data refine this chronology. Later, a phase of rapid sedimentation occurred between 1030 and $1220 \mathrm{AD}$ and $1280-1400 \mathrm{AD}$, as documented in the Station core (Unit 3). It is associated with high energy deposits, close to the main channel in the College core, and more distal deposits in the Station core, implying a rapid decrease in channel energy.

\subsection{Saint-Etienne-de-Villerase core}

The Saint-Etienne-de-Villerase core is located in the distal part of the north alluvial lobe of the Tech River (Fig. 2). The toponymy of "Villarase", in Catalan "destroyed village", is significant. The SaintEtienne-de-Villerase chapel seems to be buried by at least $1.50 \mathrm{~m}$ of alluvial deposits (Fig. 5). The core was obtained around $20 \mathrm{~m}$ northeast of the chapel. The ground level is $6.50 \mathrm{~m}$ asl. The core is 


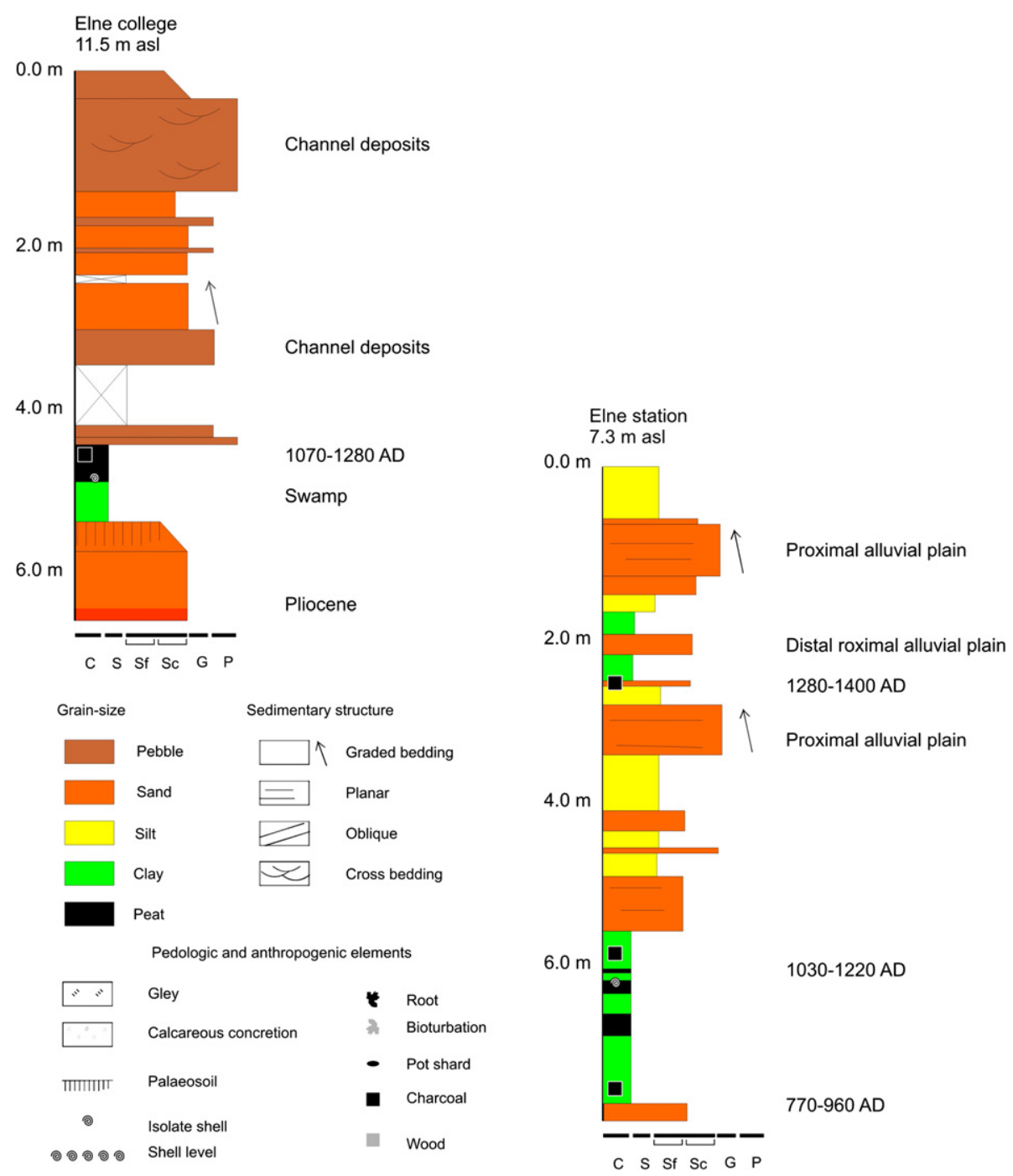

Fig. 4. Alluvial sequence in Elne: a- Core sequence in Elne College; b- Core sequence in Elne station.

8.40 m deep, did not reach the Pliocene bedrock, and can be divided into 6 main units.

In the lower part, the first metre is represented by coarse laminated sorted sands (Unit 1). It is overlain by black clay with rare interbedded fine sand layers (Unit 2). A transition to emerged land occurred around $4.20 \mathrm{~m}$ depth $(2.3 \mathrm{~m}$ asl) with fine silt to sand layers (Unit 3). The upper part of the core shows alternating silt and sand layers, with well-developed palaeosols at $2.70 \mathrm{~m}, 3.25 \mathrm{~m}, 4.3 \mathrm{~m}$

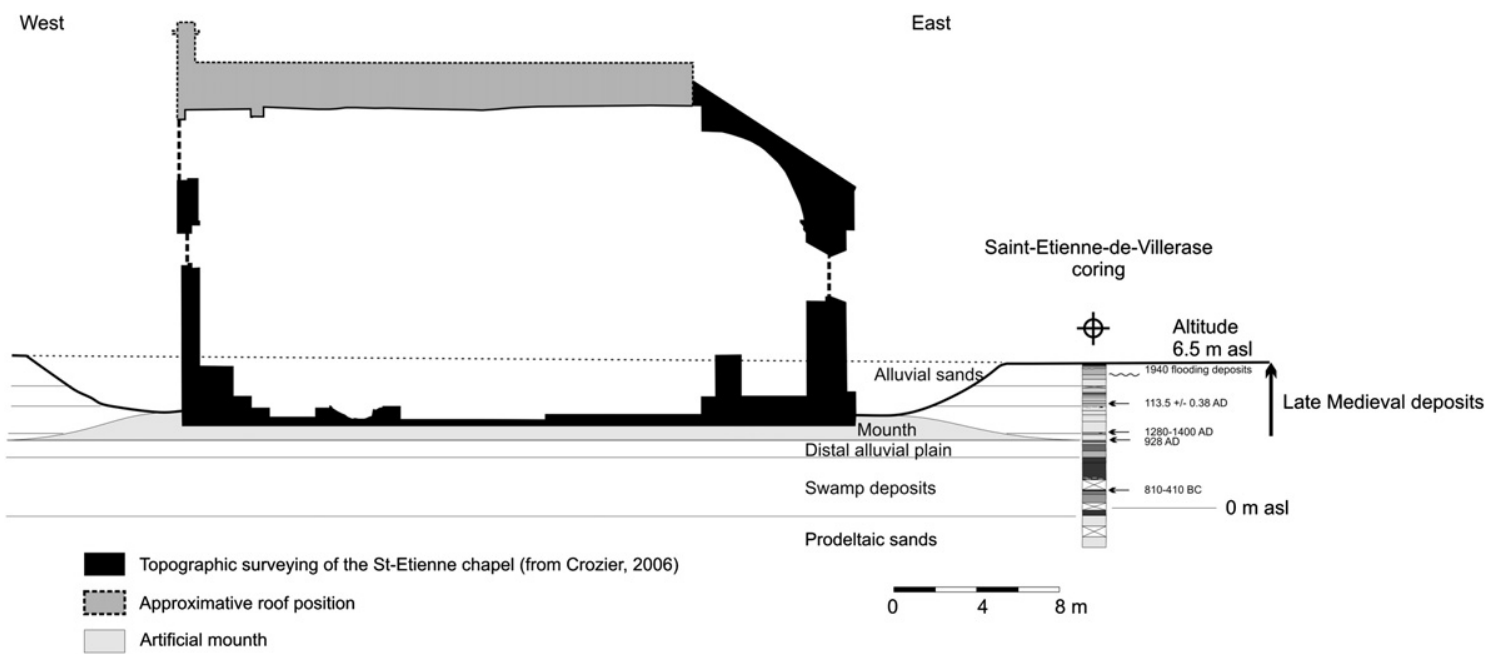

Fig. 5. Alluvial sequence in Saint-Etienne-de-Villerase chapel. 
and $5.0 \mathrm{~m}$ asl (Unit 4). The first one is correlated with the chapel building as indicated by the first occurrence of artefacts in the core.

The chronostratigraphy of this sequence can be deduced from 3 radiocarbon dates and archaeological information inferred from the chapel palaeosol. The first half of Unit 2 was dated from the 9th to 5 th century. This unit indicates the development of a swamp zone, close to the sea-level, developing above marine or prodeltaic sands (Unit 1). In Unit 3, progressive enrichment in fine sand records an increase in clastic input into the swamp. Land emerged around the second half of the first millennium. The palaeosol correlated with the chapel is clearly identified $2.70 \mathrm{~m}$ above the present day top soil. According to historical information, it could be attributed to around $926 \mathrm{AD}$. A change in sedimentation occurred between the 10th century AD and 1280-1400 AD with the deposition of a first coarse sand layer. The lower part of Unit 4 consists in successive sorted fining-up sand related to distal flood deposits. The main alluvial phase occurred prior to the 16th century AD, but radiocarbon and archaeological dating fail to document the rhythm of deposition during the Modern period.

\subsection{Mosselon trench}

The surveying of an NE-SW, $1.6 \mathrm{~km}$ trench between Elne and Mossellon provided the opportunity to view a continuous crosssection of the north alluvial lobe of the Tech river (Figs. 2 and 6). One of the interests of this site is that Mossellon is a well-known abandoned and vanished village. The vicissitudes of its abandonment are amply documented (Passarrius and Illies, 2009) but its location is poorly constrained. Trenches reaching $2.50 \mathrm{~m}$ depth were dug at $65 \mathrm{~m}$ intervals. In addition, two deeper trenches reaching $4.00 \mathrm{~m}$ were also excavated in the central part of the transect (log 16 and 17). Six main units are recognized.

The lower units $(1,2)$ were only observed in trenches 16 and 17. Unit 1 , between 0.5 and $1 \mathrm{~m}$ asl, is a black graded bedding organic sand. Unit 2 is structureless argillaceous, rich in organic remains. In particular, the upper part of this unit shows undisturbed reed roots in living position, allowing radiocarbon dating. Unit 3 is a 2.80-3.00 m thick silt to fine light brown sand. In the eastern part, small secondary sand to gravel channels were observed in trenches
13 and 15. Distal facies (i.e. silt, fine sand) are dominant at the base of the sequence and coarsen-up. Unit 4 is only recognized in the western part of the cross-section. It is a coarse sand-dominated unit with rare isolated gravel channels (trench 7 and 24). Unit 5 is the coarser unit of the sequence. Its contact is deeply erosional over Unit 4 . It is constituted by channels between 40 and $70 \mathrm{~m}$ wide and 1 to 1.50 deep, with proximal coarse sand deposits. Unit 6 is largely disturbed by tilling and cultivation. It is a coarse sand unit thickening in the eastern direction. It suggests a progressive shifting of the alluvial sequences to the northeast.

Chronological information was provided by radiocarbon dating of Unit 2 and archaeological elements from Unit 5. Reed roots in living position from the upper part of Unit 2 give a terminal age for the swamp around $1215-1260 \mathrm{AD}$. The rest of the sequence is poor in chronological data. In trench 7 , the main channel infill has provided sherds attributed to Late Medieval to Early Modern time, i.e. 15th to 16th century AD. Additional historical information, mainly based on text archives, refine both the chronological and palaeogeographical framework.

\section{Historical data}

The methodology was based on the systematic cartography of the textual information related to river position (Fig. 7). These include direct mention of river or ford position, indirect indication by boat crossing, or indication of abandoned channels. Based on this cartography, channel avulsion can be reconstituted and compared to field data to refine the chronology of the Tech defluviation. In addition, information about villages and chapels were taken into account.

The oldest text helpful to locate the Tech River is the $956 \mathrm{AD}$ mention of a boat crossing between Elne and Sainte-Eugénie-deTresmall, close to the city of Elne in the southern part of the territory. This clearly indicates the position of the Tech River to the south of Elne. It is consistent with geoarchaeological data describing a probable Tech medieval channel near Mas Reig (Pezin and Chevillot, 1997). In $1291 \mathrm{AD}$, in the western part of Elne city, a chapel called "Notre-Dame-du-Pont" is indicated on the Tech bank. This mention clearly gives an ante quem for an avulsion of the
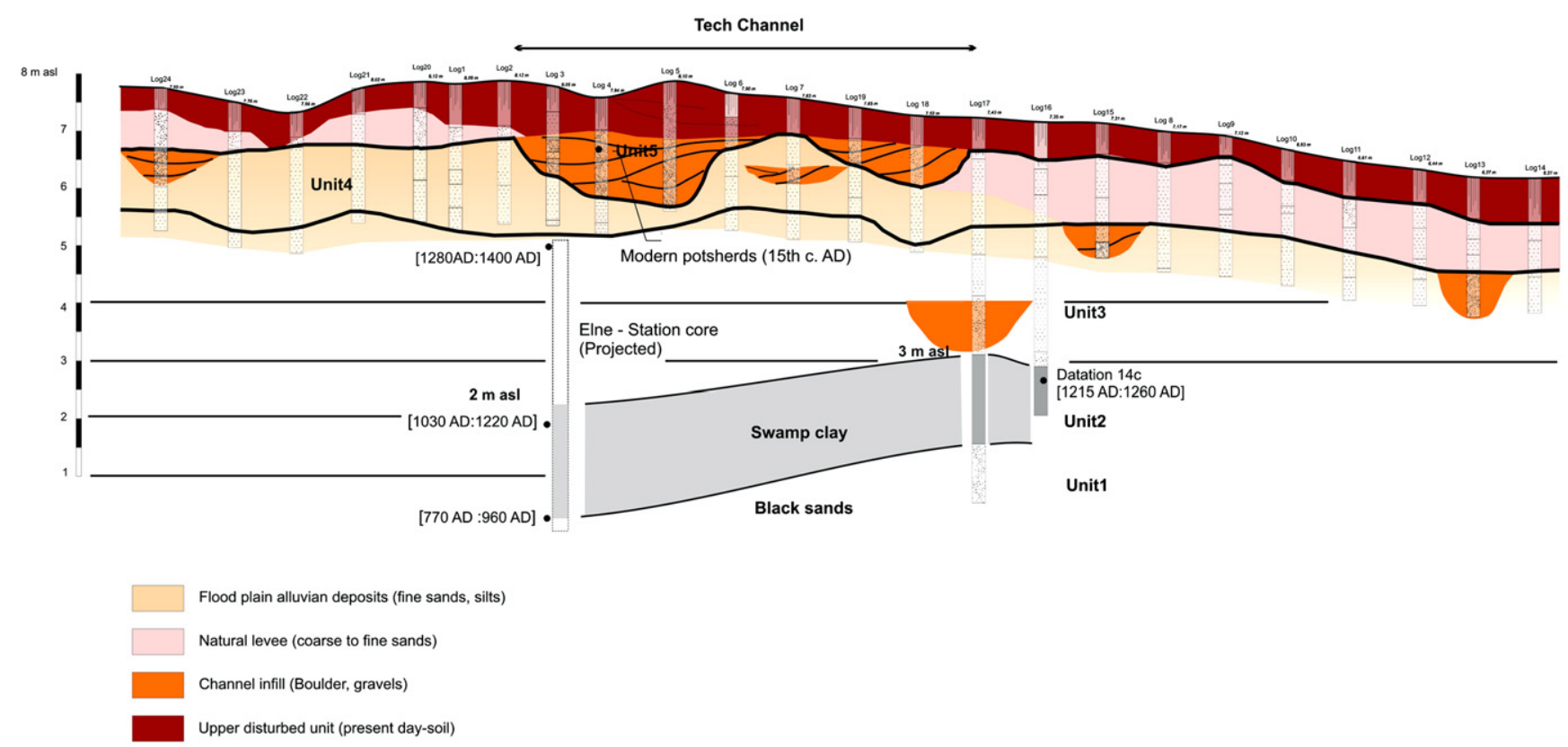

Fig. 6. Alluvial sequence in Mossellon trench. 


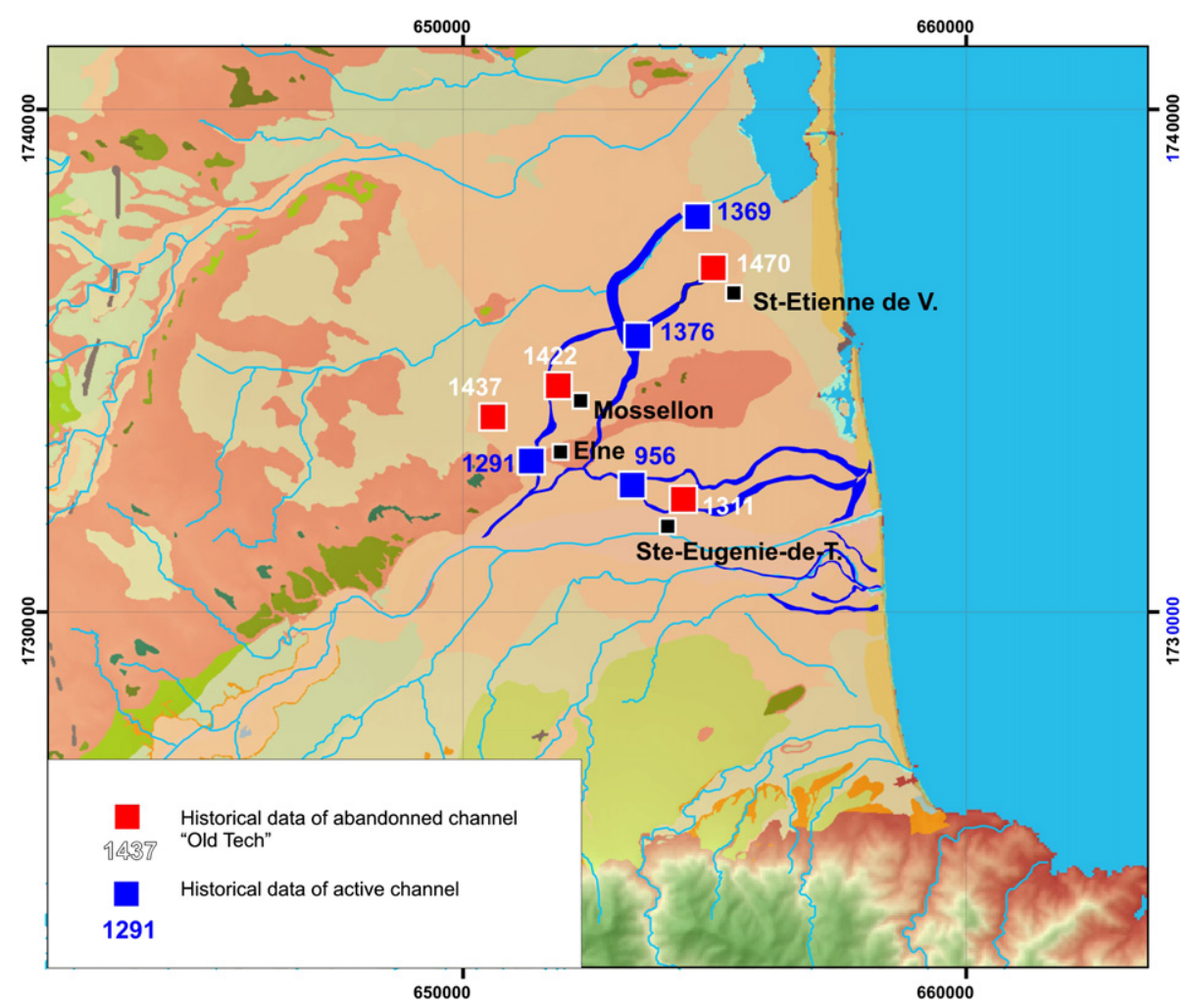

Fig. 7. Map of Tech River position according to historical data.

Tech from a southern position during the 10th century to a western course prior to $1291 \mathrm{AD}$. A few years later, in 1311, in the territory of Sainte-Eugénie-de-Tresmall, an "Old Tech" channel is mentioned.

Historical information indicates that repeated floods caused depopulation of Mossellon around 1330. In 1422, an "Old Tech" channel is mentioned close to the village. Additional information is also available around the Saint-Etienne-de-Villerase village. In 1376 , a channel island is mentioned close to Saint-Etienne-deVillerase, indicating that the avulsion channel was still active. In 1444, Gabriel Bolet mentions in Villarase a place called "Tetis Veteris" (Old Tech), which implies that the Tech River had already changed its course to an eastern or southern position at that date.

Based on these elements, the avulsion took place during the last years of the 13th century and ceased in the second half of the 14th century AD. During flood events, abandoned channels were probably reactivated and could cause severe damage to the villages and territories.

The role of large floods in the avulsion process seems to be confirmed by historical data (Puig, 2009). The oldest indication of flooding in northern Catalonia is the 878 event (Champion, 1858), but the nature and chronological attribution of this event is still controversial. More documented is the exceptional 1264 flood in Perpignan and the surrounding area. Later, minor floods are also mentioned in $1290,1327,1332,1338,1340,1370,1378$ and 1419 . The major flood of the millennium seems to be the 1421 one, which could have played a key-role in the fluvial network reorganization.

\section{Discussion}

After $1000 \mathrm{AD}$, the Roussillon plain and in particular the lower Tech River, experienced a phase of drainage network reorganization in relation with serial avulsions. Geoarchaeological and historical data clearly indicated that a major break in alluvial dynamics occurred during the late 13th century AD. The alluvial system shifted from a low water level regime (LWR) to a flood dominated regime (FDR). The geomorphological consequences were an increase in sedimentation rate (i.e. rapid aggradation in the lower plain), major and repeated avulsions associated with enlargement of the flood plain, and change in particle size deposits from silt to fine sand to coarse sand in the flood plain.

Change in particle size is clearly perceived in the Sainte-Eugéniede-Tresmall core and trench after the chapel building, i.e. $1000 \mathrm{AD}$. As indicated by historical sources and confirmed by Pezin and Chevillot (1997), the chapel remained close to the Tech River from the 10th century AD. An increase in particle size could not be correlated with channel rapprochement. This change is also seen in the Elne Station and Elne School cores, and in Mossellon trench which documents alluvial fan progradation over a swamp zone. Precise quantification of this change is still in progress. Moreover, this change is accompanied by flood plain expansion, in particular to the north of Elne city. Overflow in the Corneilla-del-Vercoll lowland across the Elne low did not result in exceptional high water level of the 13th to 15th century floods, but resulted in rapid aggradation in the lower plain. A change in mean aggradation rate is perceived in the Sainte-Eugénie-de-Tresmall core (Fig. 8) but chronological data remains poorly constrained (after the 10th century AD). During Antiquity to Early Medieval time, mean sedimentation rate is low, around $1.0 \mathrm{~mm} \mathrm{y}^{-1}$. In the last millennium, the average sedimentation rate increased to $5.3 \mathrm{~mm} \mathrm{y}^{-1}$, showing a reducing trend during the last 500 years. Such evolution in sedimentation rate is also documented in Saint-Etienne-de-Villerase. Here, the mean sedimentation rate increased from $1.4 \mathrm{~mm} \mathrm{y}^{-1}$ since the 10th century $\mathrm{AD}$, to $4.3 \mathrm{~mm} \mathrm{y}^{-1}$ during the last 650 years.

The major avulsions of the Tech River can be dated by comparing field and historical data. Field data dates the avulsion to the 1030-1280 AD interval. Historical data are consistent whit this attribution and document an active channel prior to 1290 north of Elne city. The abandonment of this channel occurred prior to 1500 


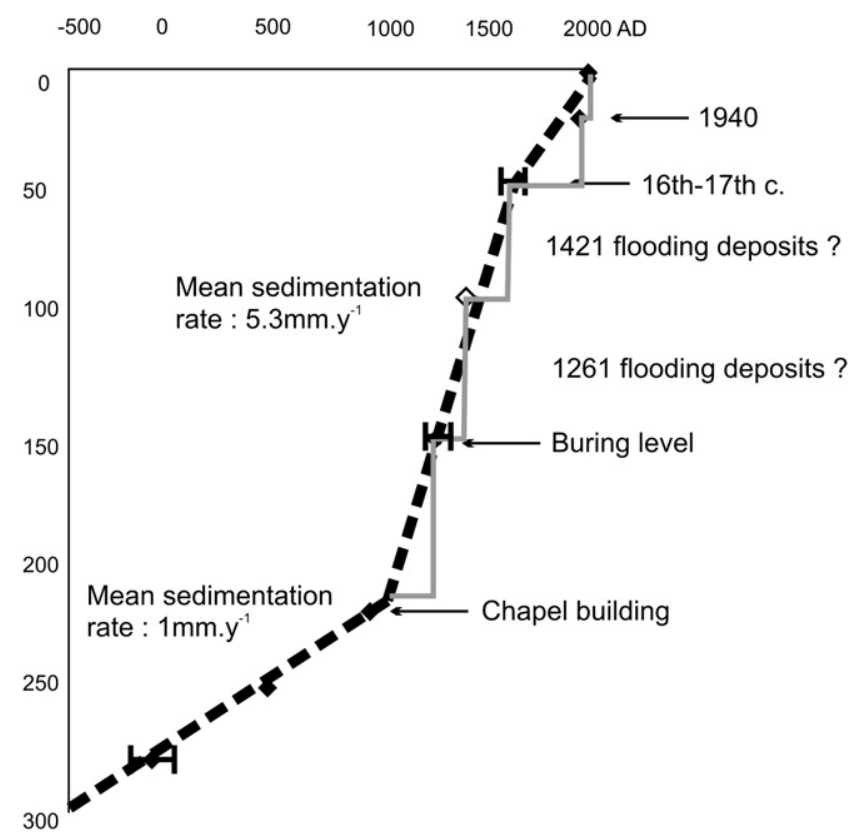

Fig. 8. Age model, Saint-Eugénie-de-Tresmal.

$A D$, according to the sedimentation rate curve. Historical data agree with this assumption and date the second channel avulsion to around 1376-1422. There is no evidence of an anthropogenic intervention to relocate the channel to its original position, and this second avulsion is supposed to be natural. Rapid aggradation in the
Corneilla-del-Vercoll low may be the cause of this second avulsion. The period from around 1250 to $1450 \mathrm{AD}$ appears to be a key one in understanding landscape evolution in the Roussillon basin. The change in fluvial dynamics in the Roussillon around the last 13th century to 15th century AD needs to take in consideration both climatic and anthopogenic possible causes (Fig. 9).

Historical studies have pointed out that during late Middle Ages, feudalism lead to an increase in population and arable land in Catalunya (Bonnassié, 1979) as well in lower plain and mountain environments. From the 12th century AD, the Roussillon villages were established in the plain. Settlements formed a network of grouped habitats, commonly around the chapel (Catafau, 1997). In the surrounding high mountain area, temporary or permanent settlements are documented by direct archaeological studies or indirectly by palaeoecological studies. Late Middle Age land transformations are related to cultivation, transhumance and grazing (Galop, 1998; Rendu, 2003), and forest clearance for charcoal and timber exploitation (Izard, 1999). Iron mining as well as forges during the last eleventh century also contributed to transform both landscape and river (Izard, 1999). The 14th century AD was marked by demographic, economic and social crisis. Black plague is often proposed as a major cause for demographic drop, cropping retraction and village abandonment since 1348 . Recent high resolution multiproxy data in south Catalonya (Ejarque et al., 2009) suggests that the Late Middle Ages to Modern period is marked by two severe crises in mountain exploitation, 1240/1380 AD and 1530/1580 AD. Repeating traditional historiography, the first one is correlated with health causes, mainly Black Plague, and the second one to Little Ice Age (LIA) effects. The 1240-1380 AD crisis reached its height around 1329 AD, marked by a peak in Pinus pollen and maximum decline in Poacea and Cerealia-type pollens (Ejarque et al., 2009).

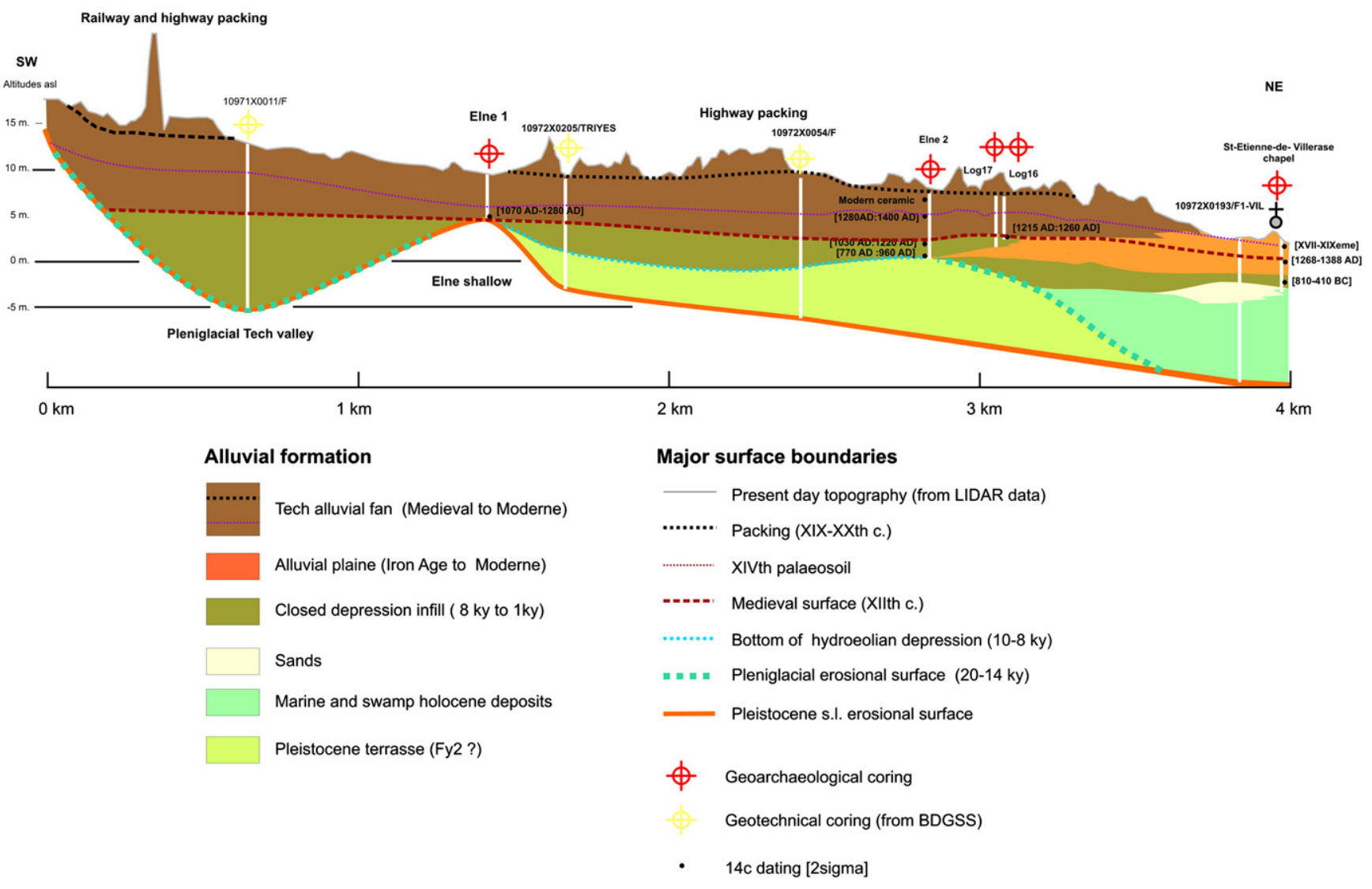

Fig. 9. Synthetic cross-section of the 13-15th century north Tech lobe. 
This date is earlier than the Black Plague epidemic disease. 1332/ 1333 AD is well-known in the Aragon kingdom as "Mal Any Primer" (the first bad year) and is the high point of flooding events initiated in 1252-1264 AD. Decline in anthropogenic pressure on mountains coincided with an increase in flood events. This climate hypothesis is also consistent with the high level recorded at Estanya Lake around 1250/1300 AD by Morellón et al. (2010). In southeast Spain, Martin-Puertas et al. (2008) also recorded two phases of high watertable in Zoñar Lake, centred on 1200-1400 AD and around 1600 AD. The last one matches well with the severe phase of the LIA (Luterbacher et al., 2005). It also agrees with Lambs et al. (1999), who reported maximum wetness around 1250/1400 AD across the Mediterranean basin. Moreover, data reported by Ejarque et al. (2009) about the well-known 1550/1600 AD climatic crisis produce similar effects on land occupation and use despite differences in social context. The last 13th century break in alluvial dynamics in the lower Tech River does not record a local event, but seems connected to a regional wet climatic event in western Mediterranean. Due to the small extents of their watersheds and torrential regimes, the response time between different parts of the basin seems largely synchronous.

\section{Conclusion}

Rapid transformation in the Tech River network is recorded during the last millennium. Repeated avulsion seems a consequence of an aggradation phase in the lower plain starting around 1250-1280 AD. Major floods, such as 1264 or 1421, play a key-role in river avulsion. At a regional scale, similar changes occurred at the same time and document regional climatic degradation, i.e. a wetter period, associated with the beginning of LIA, culminating around 1330 . The $1250 / 1330$ could be regarded as a transition from the Medieval Climate Anomaly (MCA) to Early Little Ice Age (ELIA).

The consequences of the late 13th century AD changes in social system are still difficult to evaluate. The lower plain seems to have been largely affected by hydrological transformations and social adaptation to these new conditions in the early 14th century (Carozza and Puig, in press). Technical (embankments, river gauging) and territorial (settlement abandonment, cultivation practices) adaptation may be driven by climatic transformation and its consequences on river water regime, and particularly flood frequency.

\section{References}

Arnaud-Fassetta, G., 2007. L'hydrogéomorphologie fluviale, des hauts bassins montagnards aux plaines côtières: entre géographie des risques, géarchéologie et géosciences, vol. 3. Habilitation a` diriger des recherches, Paris. 7.

Baartman, J.E.M., Veldkamp, A., Schoorl, J.M., Wallinga, J., Cammeraat, L.H., 2010. Unravelling late Pleistocene and Holocene landscape dynamics: the upper Guadalentín basin, SE Spain. Geomorphology 125, 172-185.

Bach, J., 2005. Trets geologics de la plana litoral d'Alt Emporda. Empuries 54, 13-23.

Barrera, A., Barriendos, M., Llasat, M.C., 2005. Extreme flash floods in Barcelona country. Advances in Geosciences 2, 111-116.

Benito, G., Thorndycraft, V.R., Rico, M., Sánchez-Moya, Y., Sopeña, A., 2008. Palaeoflood and floodplain records from Spain: evidence for long-term climate variability and environmental changes. Geomorphology 101, 68-77.

Berger, J.-F., Blanchemanche, P., Reynès, C., Sabatier, P., 2010. Dynamiques fluviales en basse vallée du Vidourle au cours des six derniers siècles. Quaternaire 21, 27-41.

Bisaro, V., Carozza, J.-M., 2009. Le ravin de la Berne. Document Final de Synthèse, 3 tomes. Service Régionale de l'Archéologie Languedoc-Roussillon, Montpellier.

Bonnassié, P., 1979. Catalunya mils anys enrere. Creixement economic i adveniment del feudalisme a Catalunya de mitjan segle X al finals del segle XI Edicions 62.

Bruneton, H., Provensal, M., Devillers, B., Jorda, C., Ollivier, V., Miramont, C., Blanchemanche, P., Berger, J.-F., Leveau, P., 2002. Relations entre paléohydrologie et morphogenèse holocènes des petits et moyens bassins-versants en basse Provence et Languedoc oriental. In: Bravard, J.-P., Magny, M. (Eds.), Les fleuves ont une histoire. Errance, Paris, pp. 259-268.

Calmel-Avila, 2000. Étude des paléoenvironnements holocènes dans le bassin du Bas-Guadalentín (région de Murcie, Espagne). Géomorphologie: Relief, Processus, Environnement 6 (3), 147-159.
Calvet, M., 1996. BRGM Edit, 255. Morphogenèse D’une Montagne Méditerranéenne. Les Pyrénées orientales, 3 tomes. Orléans.

Calvet, M., Serrat, P., Lemartinel, B., Marichal, R., 2002. Les cours d'eau des Pyrénées Orientales depuis 15000 ans. Etat des connaissances et perspectives de recherche. In: Bravard, J.-P., Magny, M. (Eds.), Les fleuves ont une histoire. Errance, Paris, pp. 279-294.

Carozza, J.-M., 1998. Evolution des systèmes géomorphologiques en contexte orogénique. L'exemple des bassins du Roussillon. PhD. Univ. Toulouse II, p. 398.

Carozza J-M, Puig C (in press). Changements environnementaux, vulnérabilité et adaptation des sociétés du passé: exemple du Petit Age Glaciaire en Roussillon (XIIIe - XVle s.) Sud Ouest Européen, 3.

Carozza, J.-M., Odiot, T., Passarius, O., Puig, C., Péquignot, C., Valette, P., 2008. Impact du Petit Age Glaciaire sur la plaine alluviale du Roussillon. In: DeDapper, M., Vermeulen, F., Deprez, S., Taelman, D. (Eds.), Ol'man River Geoarcheological aspect of rivers and alluvial plains. University of Gent Belgium, pp. 185-197.

Catafau, E., 1997. Les celleres et la naissance du village en Roussillon. Perpignan University Press, Canet, p. 717.

Cavero, J., 2010. Paléogéographie des étangs narbonnais d'après les sources cartographiques anciennes. Géocarrefour 85 (1), 29-40.

Champion, M., 1858. Les inondations en France du IVe siècle à nos jours. Quae Editions.

Devillers, B., Bonnet, S., 2006. 6000 ans d'histoire environnementale de la lagune de Villepey (Fréjus, Var): Premiers résultats de l'étude multi-proxies de la carotte Vil2. Archéométrie 30, 197-203.

Ejarque, A., Julia, R., Riera, S., Palet, J.M., Orengo, H., Miras, Y., Gascon, C., 2009 Tracing the history of highland human management in the eastern PrePyrenees: an interdisciplinary palaeoenvironmental study at the Pradell fen, Spain. The Holocene 19, 1241-1255.

Galop, D., 1998. La forêt, l'homme et le troupeau dans les Pyrénées. 6000 ans d'histoire de l'environnement entre Garonne et Méditerranée. PhD. GEODE, Universiteć de Toulouse II, p. 285.

Gamez, D., 2007. Sequence Stratigraphy as a tool for water resources management in alluvial coastal aquifers: application to the Llobregat delta (Barcelona, Spain). PhD. Technical University of Catalonia, Barcelona, p. 177.

Gamez, D., Simo, J.A., Vasquez-Sune, E., Salvany, J.M., Carrera, J., 2005. Variación de las tasas de sedimentación en el Complejo Detrítico Superior del Delta de Llobregat (Barcelona): su relación con causas eustáticas, climáticas y antrópicas. Geogaceta 38, 175-178.

Gutierrez-Elorza, M., Peña-Monne, J.L., 1998. Geomorphology and late Holocene climatic change in Northeastern Spain. Geomorphology 23, 205-217.

Izard, V., 1999. Les montagnes du fer. Eco-histoire de la métallurgie et des forêts dans les Pyrénées méditerranéennes (de l'Antiquité à nos jours). Pour une histoire de l'environnement. PhD. Université Toulouse II.

Jorda, C., 2007. Morphogenèse alluviale et paléogéographie d'un paysage deltaïque: le cas de Port Ariane (Lattes). Lattara 20, 41-82.

Jorda, M., Provensal, M., 1996. Impacts de l'anthropisation et du climat sur le détritisme en France du sud-est (Alpes du sud et Provence). Bulletin Société Géologique de France 167 (1), 159-168.

Jorda, M., Miramont, C., Rosique, T., Sivan, O., 2002. Evolution de l'hydrosystème durancien (Alpes du Sud, France) depuis la fin du Pléniglaciaire supérieur. Errance, Paris. In: Bravard, J.-P., Magny, M. (Eds.), Les fleuves ont une histoire, pp. 239-249.

Lambs, H.F., Gasse, F., Benkaddour, A., El Homauti, N., van der Kaars, S., Perkins, W.T. Pearce, N.J., Roberts, C.N., 1999. Lake evolution in a semi-arid montane environment: response to catchment change and hydroclimatic variation. Journal of Paleolimnology 21, 325-343.

Luterbacher, J., Xoplaki, E., Casty, C., Wanner, H., Pauling, A., Küttel, M. Rutishauser, T., Brönnimann, S., Fischer, E., Fleitmann, D., Gonzalez-Rouco, F.J. Garcia-Herrera, R., Barriendos, M., Rodrigo, F., Gonzalez-Hidalgo, JC., Saz, M.A., Gimeno, L, Ribera, P, Brunet, M, Paeth, H, Rimbu, N, Felis, T, Jacobeit, J Dünkeloh, A, Zorita, E, Guiot, J, Türkes, M., Alcoforado, M.J., Trigo, R, Wheeler, D, Tett, S, Mann, ME, Touchan, R, Shindell, DT, Silenzi, S, Montagna, P, Camuffo, D, Mariotti, A, Nanni, T, Brunetti, M, Maugeri, M, De Zerefos, C, Zolt, S, Lionello, P, 2005. Mediterranean climate variability over the last centuries: a review. Developments in Earth and Environmental Sciences 4, 27-48.

Marichal, R., Rebe, I., Treton, R., 1994. La transformation du milieu géomorphologique de la plaine du Roussillon et ses conséquences sur son occupation. Premiers résultats. In: Burnouf, J., Bravard, J.-P., Chouquer, G. (Eds.), La dynamique des paysages protohistoriques, antiques, médiévaux et modernes. APDCA, Sophia Antipolis, France, pp. 271-284

Marquès, M.A., Julia, R., 2006. Evolucion de la zona litoral del Ampurda durante el ultimo milenio. In: Sanjaume, E., Mateu, J.F. (Eds.), Geomorfologia litoral i quaternari Homenatge al professor Vicenç M. Rosselló i Verger. Valencia University Press, pp. 259-272.

Martin-Puertas, C., Valero-Garcés, B.L., Mata, M.P., Gonzalez-Samériz, P., Boa, R. Moreno, A., Stefanova, V., 2008. Arid and humid phases in southern Spain during the last 4000 years: the Zoñar Lake record, Cordoba. The Holocene 18 (6), 907-921.

Miall, A., 1998. The Geology of Fluvial Deposits. Springer, Berlin.

Montaner Roviras, J., Solà Subiranas, J., 2004. Reconstrucció d'estadis paleogeogràfics recents a la plana del Baix Ter. Papers de Montgri 23, 8-26.

Morellón, M., Valero-Garcés, B., González-Sampériz, P., Vegas-Vilarrúbia, T., Rubio, E., Rieradevall, M., Delgado-Huertas, A., Mata, P., Romero, Ó. Engstrom, D.R., López-Vicente, M., Navas, A., Soto, J., 2010. Climate changes and human activities recorded in the sediments of Lake Estanya (NE Spain) during the Medieval Warm Period and Little Ice Age. Journal of Paleolimnology. doi:10.1007/s10933-009-9346-3. 
Mussot, M., 1993. La crue d'Octobre 1940 et lits fluviaux: observations et remarqiues complémentaires. L'aiguat del 40. Generalitat de Catalunya Ed. 103-114.

Passarrius, O., 2005. Eglise Sainte-Eugénie-de-Tresmals. Document Final de Synthèse. Service Régionale de l'Archéologie Languedoc-Roussillon, Montpellier, p. 103.

Passarrius, O., Illies, P., 2009. Contournement nord d'Argelès-sur-Mer. Document Final de Synthèse. Service Régionale de l'Archéologie Languedoc-Roussillon, Montpellier, p. 78.

Pezin, A., Chevillot, P., 1997. RN 114. Etude d'impact archéologique de la déviation d'Elne. Document Final de Synthèse. Service Régionale de l'Archéologie Languedoc-Roussillon, Montpellier, p. 77.

Pichard, G., Ricaute, N., 2009. Une déclinaison régionale du Petit Age Glaciaire. Apport des archives historiques de Provence. Archéologie du Midi Médiéval 27, 237-247.

Puig, C., 2003. Les campagnes roussillonnaises au Moyen Age: pratiques agricoles et paysagères entre le XIle et la première moitié du XIVe s. PhD. Université Toulouse II, p. 918.

Puig, C., 2009. Les prémices du Petit Age Glaciaire en Roussillon à travers le prisme des sources écrites. Archéologie du Midi Médiéval 27, 191-205.

Rendu, C., 2003. La montagne d'Enveig. Une estive pyrénéenne dans la longue durée. Trabucaire, p. 620.

Rey, T., Lefevre, D., Vella, C., 2009. Deltaic plain development and environmental changes in the Petite Camargue, Rhone Delta, France, in the past 2000 years. Quaternary International 171, 284-294.
Schulte, L., 2002. Climatic and human influence on river systems and glacier fluctuations in southeast Spain since the last Glacial Maximum. Quaternary International 93-94, 85-100.

Schulte, L., 2003. River-response and terrace aggradation in the Mediterranean Iberian Peninsula during historical times. In: Thornsdycraft, V.R., Benito, G., Barriendos, M., Liasat, M.C. (Eds.), Palaeofloods, Historical Data and Climate Variability. European Commission Consejo Superior de Investigaciones Cientificas, Madrid, pp. 67-72.

Serrat, P., 2000. Génèse et dynamique d'un système fluvial méditerranéen: le bassin de l'Agly. PhD. Université Perpignan, p. 720.

Sheffer, N.A., Enzel, Y., Benito, G., Grodek, T., Porat, N., Lang, M., Naulet, R., Coeur, D., 2003b. Paleofloods and historical floods of the Ardeche River, France. Water Resources Research 39, 1376.

Sivan, O., Dubar, M., Court-Picon, M., 2010. Les variations postglaciaires des taux de sédimentation dans les basses plaines alluviales niçoises (Alpes-Maritimes). Quaternaire 21, 61-69.

Somoza, L., Barnolas, A., Arasa, A., Maestro, A., Ress, J.G., Hernandez-Molina, F.J., 1998. Architectural stacking pattens of the Ebro delta controlled by Holocene high-frequency eustatic fluctuations, delta-lobe switching and subsidence processes. Sedimentary Geology 17, 11-31.

Verdeil, P., 1970. Nouvelles données sur la Quaternaire de la Basse vallée de l'Aude. Bulletin Societe Geologique Francais 12, 413-425.

Vita-Finzi, C., 1969. The Mediterranean Valleys. Cambridge University Press, p. 140. 